\title{
Guest editorial: the entrepreneurship challenges in Latin America
}

\author{
José Ernesto Amorós
}

EGADE Business School, Tecnológico de Monterrey, Mexico City, Mexico and School of Business and Economics, Universidad del Desarrollo, Santiago, Chile

\author{
Juan Carlos Leiva \\ Business School, Tecnologico de Costa Rica, Cartago, Costa Rica \\ Adriana Bonomo \\ Department of Management and Business, Catholic University of Uruguay, \\ Montevideo, Uruguay, and \\ Juan Carlos Sosa Varela \\ School of Business and Entrepreneurship, Universidad Ana G. Méndez, \\ Gurabo, Puerto Rico
}

\begin{abstract}
Purpose - The purpose of this paper is to introduce the special issue "The Entrepreneurship Challenges in Latin America".

Design/methodology/approach - Latin America and the Caribbean is a region with many potentialities. Like one of the largest markets in the world, entrepreneurship activities can constitute a key element to enhance regional competitiveness.

Findings - This study makes a general overview of entrepreneurship dynamics in Latin America and its contexts. This study presents the eight manuscripts that constitute the special issue.

Originality/value - This study contributes to current academic conversations and highlights the relevance of continuing inquiring about the entrepreneurship phenomena at the regional level.

Contribution to impact - This study expects that this special issue will help the region's scholarly entrepreneurship community and others interested in Latin America. This study also believes that this special issue manuscript makes a relevant contribution to policy and practice.
\end{abstract}

\section{Introduction}

New business creation is undoubtedly one of the most critical drivers of countries' economic growth, social development and competitiveness (Acs, 2006; Audretsch and Keilbach, 2004; Stel et al., 2005; Wennekers et al., 2005). As a result, there is a special interest in the role of entrepreneurs and the process that leads the establishment and development of new enterprises (Khoury and Prasad, 2016). Specially, entrepreneurship in emerging economies has

The authors extend their acknowledgments to CLADEA's Latin America Entrepreneurship Network that helps them in the design and dissemination of this special issue. J.E. Amorós extend his gratitude to Tecnologico de Monterreýs Eugenio Garza Lagüera Entrepreneurship Institute for its support.

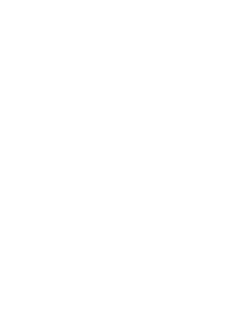


EBR

33,6

been the subject of scholarly inquiry in recent decades. However, research gaps continue to exist, and relevant questions continue to go unanswered (Acs and Virgill, 2010; Chowdhury et al., 2019; Khoury and Prasad, 2016; West et al., 2008). For example, the relevance of formal and informal institutions, the quantity and quality of financial sources (Dams et al., 2021), entrepreneurship education, demography of entrepreneurial activities, etc. The specific case of Latin America represents to the scholars a vast field of opportunities for research (Aguinis et al.2020) as the region is home to some of the largest consumer markets in the developing world and provides illuminating cases of the causes and consequences of rapid development. While Latin America has recently shown significant progress in the creation of new companies, which has been catalysed in part by government-sponsored pro-entrepreneurship policies (Acs and Amorós, 2008; Amorós et al., 2019a, Alvarez and Urbano, 2011; Capelleras et al., 2010; Alvarez et al., 2014; Kantis et al., 2021) and also attracting more venture capital (LAVCA, 2021) differences in relation to more advanced economies persist (Kelley et al., 2011) and how innovative are this new firms or if there are other manifestations of entrepreneurial endeavours such as intrapreneurship (Bosma et al., 2013).

To enhance and contribute to the current conversation about the relevance of entrepreneurship, focusing on Latin America, we present this special issue. This editorial presents some of the relevant topics and challenges that entrepreneurship dynamics face in the region and introduce each of the manuscripts that constitute the issue. We conclude with some reflections and further research lines that could contribute to academia, practitioners and policymakers who want to improve Latin America entrepreneurship ecosystems.

\section{The Latin America context}

Latin America and the Caribbean (LAC) [1] is a region with great economic potential. With a population of about 670 million people and a total gross domestic product of approximately $\$ 5.73 \operatorname{tn}$ (2019, current US\$), the region also hosts two of the world's largest economies: Brazil and Mexico. Many countries in this region have made significant reforms over the past three decades, increasing the role of the private sector in promoting economic growth and highpowered incentives for efficient businesses (Aulakh et al., 2000; Amorós et al., 2019a). In addition, the region has made many efforts in democratization, property rights and macroeconomic stability. The region's remarkable resilience to the crisis of late 2008 and 2009 was also evident (Sala-i-Martin et al., 2010).

However, LAC is a region of paradoxes. For many years, the enormous reserves of natural resources have permitted several industrialization processes (i.e. Brazil, Mexico), but at the same time, the "commodities trap" also down or deteriorated some national economies, being the extreme case of Venezuela. Like the region, persist a relative facility to do business across national borders (i.e. Mercosur). Additionally, there are relatively few conflicts, few cross-country rivalries compared with other parts of the world. However, at the same time, LAC has several institutional voids, high levels of corruption, weak market infrastructures, economic volatility, populism and a growing social and economic inequity (Aguinis et al., 2020). For example, since 2014, the region has experienced the weakest period of growth since 1950 and exhibited lower growth than the OECD average, with almost no expansion of the economy in 2019 and a critical situation in 2020 related to the COVID-19 pandemic (OECD, 2020). Precisely the Coronavirus situation demonstrates (again) that these paradoxes could be accentuated, mainly because of the increase of inequities and poverty situations (World Bank, 2020).

According to the Global Entrepreneurship Monitor (GEM) reports, LAC countries present one of the highest rates of new firm creation across the world (Bosma et al., 2021). GEM indicators also show that LAC countries are characterized by high levels of entrepreneurial attitude and opportunity recognition. In contrast, a large percentage of entrepreneurs in the 
region are "survival entrepreneurs" who, to survive, operate in the informal economy because they cannot afford the costs of the formal sector. Many of these entrepreneurial endeavours are self-employment with relatively low value-added (OECD, 2021)

In counterpart, some regions, such as Southeast Asia and Eastern Europe, have a remarked transformation in recent decades, both in economic growth and institutional development. Some of the causes of the relatively poor performance in LAC is that the region continues to present areas of opportunity in various aspects such as education, knowledge creation and the need for some economics (and political) reforms which has meant lower economic and competitive outcomes compared to other emerging markets.

\section{The entrepreneurship challenges in Latin America: an overview of the special issue manuscripts}

As we commented in the previous section, many of the structural problems that LAC face also cause more difficulties in the development of activities related to innovation, entrepreneurship and the creation of new companies (Acs and Amorós, 2008; West, et al., 2008; Terjesen and Amorós, 2010; Amorós, 2011; Amorós et al., 2019a; Kantis et al., 2020).

Despite the difficulties (absolute and relative), the phenomenon of entrepreneurial initiative in LAC has become a rapidly expanding field (Kantis et al., 2002; Kantis, 2005; Amorós et al., 2021; Alvarez et al., 2014; Amorós et al., 2016; Lopez and Alvarez, 2018; Aguinis et al., 2020; Cancino et al., 2020). With the beginning of 21 century, Peres and Stumpo (2002) show that start-ups and small- and medium-sized enterprises should not be considered secondary actors in the industrial structure of the countries of the region, as these companies can create jobs (or generate self-employment in the case of selfemployment), but it can also help to "rejuvenate" all regional economies (Capelleras et al., 2010). Tiffin (2004) demonstrated the growing interest and multiple impacts of entrepreneurship issues in almost every country in the region. In addition, from the field of public policy, many LAC governments emphasize business activities, including creating new enterprises and self-employment, as these activities can significantly improve social and economic development (Amorós et al., 2019b).

The works in this special issue result from a call to submit original research that emphasizes approaches to entrepreneurship from the perspective of Latin America and the Caribbean. Notwithstanding the primary focus of the special issue, we also consider works that deal with other emerging or developing regions (for example, Asia, Africa, etc.) and their relationship with LAC, or relationships between developed economies and the region. From the call, we received 30 papers that the editors and peers evaluated. It was not easy to select the final eights works. However, we firmly believe that selecting these manuscripts could contribute to a specific regional lens of entrepreneurship literature.

Lafuente and Vaillant (2021) in their paper "Pulling from the front or pushing from behind: how competency prioritisation should differ to optimise firm competitiveness", recognize that competitiveness is a crucial output of an economy's entrepreneurial and business activity. Specific competencies, such as innovativeness and technological capabilities, have become requisites for competing in a "Smart" economy. However, not all firms optimize their competitive efficiency to maximize their potential in the same way, and there is no "one size fits all." Also, other drivers of competitiveness, such as human capitalbased, strategic and market-oriented competencies, are "essentials" that firms must master to optimize their competitive potential (Lafuente et al., 2020). Given the distinct resource limitations and contrasting capability frontiers, the driver that should optimally be focalized is likely to differ from firm to firm (Lafuente et al., 2021). Benchmarking the best performers to encourage similar capability-building across different institutionally bonded international 
EBR 33,6

economies or uniformly among firms that are part of the same economy may be inadequate for the optimal competency configuration of less endowed and potentially poorer performers (Lafuente and Vaillant, 2021).

For these reasons, Lafuente and Vaillant (2021) contrasted the disparities in optimal competency configurations across eight European and Latin American economies. Their model analysed the competitive efficiency across firms of different performance endowments to identify distinctions and determine whether standardized or customized competitiveness configurations were optimal. Specifically, the authors compared the competitive efficiency of top- and poor-performing firms across five European countries (Bosnia, Czech Republic, France, Hungary, Spain) and three Latin-American countries (Colombia, Costa Rica and Mexico).

The results of the multilevel model point to important national- and firm-level distinctions across the optimal competitiveness configurations. The role of the configuration of drivers of competitiveness in the efficiency thereof provides an opportunity to assess how different competencies contribute to competitiveness in contexts where the interactions between resources and capabilities are complex and heterogeneous (Lafuente and Vaillant, 2021). Also, this study indicates that there are essential differences in attainable capability frontiers between firms from the same country, leading to distinct optimal competency configurations.

Lafuente and Vaillant (2021) found that more recent start-ups tend to experience significantly greater competitive efficiency. Also, other trends were found when separating the top-performing firms from the poor performers in each economy. The configurational outputs that potentially contribute most to competitive efficiency are not standardized. While "technology" is a critical factor for the competitive efficiency of top-performing firms, "market" competencies are most important for improving the competitive potential of poor performers. Whereas innovativeness and technological competencies are key factors for driving the competitive efficiency of top-performing firms, poor performers are found to gain the most significant competitive efficiency by prioritizing their "market" drivers within their competency configuration.

The findings of this study would appear to indicate that underperforming companies should first optimize their market and strategic drivers of competitiveness as essential competencies are not left behind. Once these objectives are reached and competitiveness has been gained, firms should move to more resource-demanding technological and innovative competency-building tasks. The maximization of firms and entrepreneurial ventures' competitive efficiency within an economy does not depend on standardized capabilitybuilding measures but on customized competitiveness configurations where resource endowment and the consequent firm performance are significant customization criteria.

Dams et al. (2021) show the importance of funding for developing start-ups in Latin America, a region characterized by small and unstable local markets. For the authors, improving start-ups' access to international financing and global commercial markets is paramount, especially for businesses required to have exponential growth. One of the essential sources of funding start-ups is venture capital (VC). The firms backed by VC funding tend to outperform their peers in innovation (Lerner, 2010), growth (Hellman and Puri, 2000) and internationalization (Fernhaber and Mcdougall-Covin, 2009). However, in emerging economies, as in many Latin American countries, the VC market is less developed. There is a lack of experienced private sector with these firms, showing that regulatory capture is much more prevalent (Karsai, 2018). Therefore, VC is even less successful in achieving good results (Alperovych et al., 2020). 
Given its relevance, public policies have attempted to foster VC development to overcome market failures related to insufficient financing available for start-ups (Alperovych et al., 2020; Colombo et al., 2016; Da Rin et al., 2006). Government initiatives to stimulate VC include government-sponsored VC funds (GVC) (Brander et al., 2015; Grilli and Murtinu, 2014) and "Hybrid Funds" (HybridVC), with professional private fund managers serving as general partners (Brander et al., 2015; Munari and Toschi, 2015).

Also, Multilateral Development Bank (MDBs) initiatives have tried to contribute to VC development in different regions, following their mission to reduce poverty and promote sustainable development (Bhargava, 2007). MDBs participate in equity investments in startups, but their engagement and relative effectiveness have remained largely unexplored. For these reasons, Dams et al. (2021) aim to examine the relative performance of multilateral development banks VC funds (MDBVCs) compared to that of government-sponsored VC funds (GVCs), assessing their impact on invested start-ups.

Their results suggest that Multilateral Development Bank initiatives outperform similar public programs (GVC and Hybrid VC) in Latin America in increase start-ups' chances of receiving subsequent rounds of financing and access to international expansion. In a region characterized by small and unstable local markets, improving start-ups' access to international financing and global commercial markets is vital, especially for businesses required to have exponential growth to be investable by $\mathrm{VC}$ funds.

In the next work, Martins, et al. (2021) examine business angel networks (BANs) development in emerging countries such as Chile and Colombia to understand how institutions affect their development. This topic is very relevant for LAC because access to credit is an essential issue in entrepreneurship. Their paper "An institutional approach to the development of BANs in Latin American emerging countries" (Martins et al., 2021) follows a qualitative, exploratory and descriptive approach based on 12 interviews with partners/managers of the active BANs in each of the countries. Specifically, they analysed the creation, operation and sustainability of the BANs. Results show differences and similarities in every dimension of analysis. The role of the formal institutions in each country and the organization of the state explain the main differences - for example, decentralized organization of the state in Colombia vs centralized in Chile. Likewise, the absence of standardized processes to the operation of BANs in Chile and the lack of legislation in Colombia.

On the other hand, informal institutions (social capital and cultural values) explain the similarities, for instance, the existence of solid in-group collectivism among investors or the strong dependency on the social capital of their members for the creation and expansion. Another interesting finding was the widespread distrust among the BANs, the investors and the entrepreneurs about sharing information. This study contributes to a critical area of expertise in promoting entrepreneurship in LAC. The authors conclude that informal institutions are more relevant than formal institutions for developing BANs in both countries. They suggest specific actions for policymakers, universities and citizens related to informal institutions. For example, to generate a VC-friendly culture in the population, sharing good practices of BANs, showing cases of success and failure of angel investors in different contexts and industries, among others. Nevertheless, formal institutions' modifications are also necessary to improve the development of BANs. In this case, a legal and regulatory framework and tax treatment are topics to consider.

Evaluate what is the role of the entrepreneurial ecosystem on different types of entrepreneurial re-entry at a global scale, by Espinoza-Benavides et al. (2021), was the purpose of the third article in this special issue: "Dissecting the ecosystems' determinants of entrepreneurial re-entry after a business failure". This paper attends a relevant call for 
EBR

33,6

discussing the positive or negative impact that starting a venture after a recent business failure can have on entrepreneurs and their environment. In this line, the authors want to contribute by debating how the context can influence the decision and behavior of re-entry. Specifically, the authors examined how entrepreneurial ecosystem pillars (formal conditions) and societal perceptions of entrepreneurship (informal conditions) influenced the entrepreneurial re-entry trajectory after failure in emerging economies. For their purpose, they applied a fixed-effect dynamic GMM estimation based on a data panel of 54 countries' economies during the period 2004-2020, mixing information sources (e.g. GEM, the World Economic Forum, the World Bank and the International Monetary Fund).

The authors proposed several conclusions and implications. It seems like the entrepreneurial ecosystem's formal conditions tend to ignore re-entrepreneurs because they primarily support high-growth entrepreneurship. From the informal condition's perspective, the conclusion is that social media plays a critical role in legitimizing entrepreneurship and supporting those entrepreneurs who want to re-enter the market after a business failure. Finally, social networks built in previous experiences have a critical role in the successful reentry process after a business failure. Espinoza-Benavides et al. (2021) propose the entrepreneurial ecosystem's formal condition look to minimize the cost of business failure, the informal conditions provide support for entrepreneurs in adverse contexts or circumstances and actors from the public and private spheres work together to improve the role of the entrepreneurial ecosystem on the entrepreneurial re-entry.

In their paper "Senior entrepreneurship in Chile: necessity or opportunity? A GEM perspective", Leporati et al. (2021) analysed very interesting and growing phenomena: the rise of entrepreneurial activity (new business creation) among older strata of the population. Using the case of Chile, the authors identify the internal factors that lead senior individuals ( +55 years old) to pursue an entrepreneurship activity, either by necessity or opportunity. They also compared with other age groups. Leporati et al. (2021) used the Adult Population Survey of the Global Entrepreneurship Monitor, GEM, Chile, for their empirical approach. The authors discuss the dichotomy about opportunity vs necessity-driven entrepreneurship activity (Amorós et al., 2019b) and find very interesting results:

- Senior entrepreneurship by necessity in Chile is more likely in the case of women. The unfortunate gap between women's and men's salary levels could also explain this pattern because having medium or high income and being a formal employee reduces the propensity of been an entrepreneur by necessity.

- Senior entrepreneurship by opportunity is mainly driven by an adequate level of education; medium or high levels of income; a relative perception of good opportunities in the market; the availability of networks; and the perception of having entrepreneurship skills.

The conclusions have several practical and policy implications. For example, governments in Latin America, specifically in Chile, could increase the rate of senior citizens' entrepreneurship to reduce the pressure on social welfare systems. With a larger life expectancy (and better health systems), many people could be involved in labour after the official retirement age. This is also related to practices of diversity and inclusion, especially the ones about reducing gender inequality in the labour market. Education is also a key element. Promoting education, especially entrepreneurship training, is a fundamental task for producing entrepreneurial activity among older people.

Frare and Beuren (2021), in their paper "Fostering individual creativity in start-ups: comprehensive performance measurement systems, role clarity, and strategic flexibility," analyse Brazilian start-ups through partial least squares modeling - structural equation 
modeling (PLS-SEM) and fuzzy-set qualitative comparative analysis (fsQCA). Facing the challenge of the 4th revolution, the issues of innovation, creativity, adaptability and performance are priorities in the survival and growth of companies in general and start-ups. The author discusses an emerging topic in start-ups, such as the gap of exploring performance measurement systems (PMS) with the financial and non-financial performance approach and some innovation metrics. Its effect on role clarity, strategic flexibility, individual creativity and the direct and indirect relationships observed between these aspects.

The authors proposed several conclusions and implications. They find the importance of comprehensive PMS as a predictor of individual creativity, role clarity and flexibility. In addition to the effect of role clarity on creativity and its partial mediation between creativity and comprehensive PMS. Faced with the challenge posed by the demands of the 4th revolution, being able to influence performance measures in innovation processes is an interesting contribution to management accounting, both in individual aspects such as creativity and cognitive aspects such as role clarity. Although there are limitations due to both sample size and methods, the authors propose future research focused on using artificial neural networks as a complement to the PLS-SEM applied.

Martínez and Muñoz (2021), in their paper "Are Andragogy and Heutagogy the Secret Recipe for Entrepreneurial Education as Common Curricula?” examined a significant issue involving the development of the entrepreneurial competencies, the lack of parameters that guide entrepreneurial education. Their initial contribution is the unification of the main classifications of the most relevant competencies to promote the creation of new ventures from the university. Then, they propose, based on Jones et al. (2014), to incorporate andragogy and heutagogy schemes according to the maturity of the students to achieve a better disposition to learning.

The approach to the construction of teaching patterns from the perspective of andragogy and heutagogy is interesting. Mainly because of the selection of an excellent case study applied to the students of the Tecnológico de Monterrey, Mexico, recognized as an entrepreneurial university in the world. An empirical design was applied to 400 students and using a Bayesian analysis focusing on competencies related to soft and technical skills obtained through transdisciplinary entrepreneurship education. The literature highlights the importance of recognizing one's competencies upon graduation. According to the results sought, authors propose a new classification of competencies that will determine the most appropriate program for university entrepreneurial education. The main implication is the recommendation of which teaching model to use according to the learning sought: andragogy if focused on the guided learning process and heutagogy if the orientation is towards self-discovery. The challenge presented by the authors is to apply it in other Latin American universities.

How human flourishing interacts with entrepreneurial self-efficacy and entrepreneurial intentions? This is the main question that Silveyra et al. (2021), inquire in our last manuscript "Human flourishing: an enabler of entrepreneurial intention in Latin American students". Human flourishing, even is a very ancient concept related with happiness and wellbeing, is gaining relevance nowadays because of the relevance of "having a good life" and not only "have a life". As Silveyra et al. (2021) refer, human flourishing is related to "living within an optimal range of human functioning, one that connotes goodness, generativity, growth, and resilience" (Fredrickson and Losada, 2005, p.1). Be an entrepreneur could be related with experiment more human flourishing (a consequence of entrepreneurial activities). However, one of the main interesting proposals of this research is that human flourishing is treated like an antecedent of entrepreneurship intentions. Many previous literatures analyse that entrepreneurship is an antecedent of well-being or other positive human being conditions (for example, Amorós et al., 2021). So, entrepreneurship intentions 
EBR

33,6

and entrepreneurial self-efficacy could be a consequence of human flourishing because entrepreneurs that feel more capable could take advantage of more entrepreneurial opportunities. Additionally, the authors analyse the role of having public or private education before higher education.

The authors collect a representative sample of 5,035 observations from one private university in Mexico. The sample's nature permitted different quantitative analyses, including structural equation modeling (SEM) and multilevel structural equation modeling (MSEM). The main results from this study confirm that higher human flourishing indicators positively impact both in entrepreneurial intentions and entrepreneurial self-efficacy of the student. These results are very relevant because they highlight that individuals, in this case students, who experiment with higher levels of human flourishing, could have positive purposes and meanings. They can be more optimistic and resilient, have good personal relationships and have a propensity to positive events that may influence their selfmotivation to achieve goodness. As the authors mentioned, many of these characteristics are essential in the pursuit of increasing entrepreneurial self-efficacy and creating a potential new venture. This study is very relevant also because, in general, the education systems in Latin America present substantial differences and asymmetries. So, independent of the public or private sector, enhancing mechanisms that provide capabilities and resources for human flourishing could be relevant for further socio-economic development.

\section{Conclusions}

The special issue articles point to an evolving but, to date, an immature field of research in entrepreneurship in Latin America. Latin America has vulnerable institutions, weak market infrastructures, high levels of corruption and volatility, populism and social and economic inequity. These challenges provide unique social, cultural and economic conditions that offer entrepreneurial researchers valuable opportunities to test theories and develop new theories (Aguinis et al., 2020).

Several of the papers in this special issue have illustrated the entrepreneurial stages and challenges, including entrepreneurship education, quantity and quality of financial sources, demography diversity and strategic flexibility of the firms, which may affect various types of entrepreneurial activity directly or indirectly. Also, the different authors highlight the critical importance of the nature of entrepreneurship - for example, formal versus informal and the ultimate purpose and effects of the activities. For some Latin American countries, the results highlight those policymakers can positively affect entrepreneurship, including several ambitious types of entrepreneurships, fostering entrepreneurship education and training, stimulating outward $\mathrm{VC}$ and the development of entrepreneurial networks. This region should work towards the efficiency-driven stage by achieving stable institutional and macro-economic environments and increasing entrepreneurial capacity.

Finally, the papers reveal that complex interdependencies may exist between individuallevel factors, such individual creativity in start-ups on the one hand, and between national environmental or institutional conditions on the other hand. The examination of institutional and environmental conditions is beneficial for public policy planning because they are more quickly sensitive to policy reforms. In contrast, individual-level factors may require more time to be affected by public policy.

\section{Note}

1. From here, to simplify the text, when referring to Latin America and the Caribbean, we will use the abbreviation LAC. 


\section{References}

Acs, Z. (2006), "How is entrepreneurship good for economic growth?", Innovations, Vol. 1 No. 1, pp. 97-107.

Acs, Z.J. and Amorós, J.E. (2008), "Entrepreneurship and competitiveness dynamics in Latin America", Small Business Economics, Vol. 31 No. 3, pp. 305-322.

Acs, Z.J. and Virgill, N. (2010), "Entrepreneurship in developing countries", Foundations and Trends® in Entrepreneurship, Vol. 6 No. 1, pp. 1-68.

Aguinis, H., Villamor, I., Lazzarini, S.G., Vassolo, R.S., Amorós, J.E. and Allen, D.G. (2020), “Conducting management research in Latin America: why and what's in it for you?", Journal of Management, Vol. 46 No. 5, pp. 615-636.

Alperovych, Y., Groh, A. and Quas, A. (2020), "Bridging the equity gap for young innovative companies: the design of effective government venture capital fund programs", Research Policy, Vol. 49 No. 10, p. 104051.

Alvarez, C. and Urbano, D. (2011), "A decade of research on GEM: achievements and challenges", Academia, Revista Latinoamericana de Administración, Vol. 46, pp. 16-37.

Alvarez, C., Urbano, D. and Amorós, J.E. (2014), "GEM research: achievements and challenges”, Small Business Economics, Vol. 42 No. 3, pp. 445-465.

Amorós, J.E. (2011), "El proyecto global entrepreneurship monitor: una aproximación desde el contexto latinoamericano academia", Revista Latinoamericana de Administración, Vol. 46, pp. 1-15.

Amorós, J.E. Borraz, F. and Veiga, L. (2016), "Entrepreneurship and socio-economic indicators in Latin America”, Latin American Research Review, Vol. 51 No. 4, pp. 186-201.

Amorós, J.E., Cristi, O. and Naudé, W. (2021), "Entrepreneurship and subjective wellbeing: does the motivation to start-up a firm matter?", Journal of Business Research, Vol. 127, pp. 389-398, doi: 10.1016/j.jbusres.2020.11.044.

Amorós, J.E., Poblete, C. and Mandakovic, V. (2019a), "R\&D transfer, policy, and innovative ambitious entrepreneurship: evidence from Latin American countries", The Journal of Technology Transfer, Vol. 44 No. 5, pp. 1396-1415.

Amorós, J.E., Ciravegna, L., Mandakovic, V. and Stenholm, P. (2019b), "Necessity or opportunity? The effects of state fragility and economic development on entrepreneurial efforts", Entrepreneurship Theory and Practice, Vol. 43 No. 4, pp. 72-750.

Audretsch, D.B. and Keilbach, M. (2004), "Does entrepreneurship capital matter?”, Entrepreneurship: Theory and Practice, Vol. 28 No. 5, pp. 419-429.

Aulakh, P., Kotabe, M. and Teegen, H. (2000), "Export strategies and performance of firms from emerging economies: evidence from Brazil", Chile and Mexico. Academy of Management Journal, Vol. 43, pp. 342-361.

Bhargava, V. (2007), "Global issues for global citizens: an introduction to key development challenges", Choice Reviews Online, Vol. 44 No. 10, pp. 57-60.

Bosma, N., Hill, S., Ionescu-Somers, A., Kelley, D., Guerrero, M. and Schott, T. (2021), Global Entrepreneurship Monitor 2020/2021 Global Report. Global Entrepreneurship Research Association (GERA): London.

Bosma, N., Wennekers, S., Guerrero, M., Amorós, J.E., Martiarena, A. and Singer, S. (2013), GEM Special Report on Entrepreneurial Employee Activity, Wellesley MA, Santiago Chile, Kuala Lumpur, Malaysia: Babson College, Universidad del Desarrollo, Universiti Tun Abdul Razak.

Brander, J.A., Du, Q. and Hellmann, T. (2015), "The effects of government-sponsored venture capital: international evidence", Review of Finance, Vol. 2 No. 19, pp. 571-618.

Cancino, C.A., Merigó, J.M., Urbano, D. and Amorós, J.E. (2020), "Evolution of the entrepreneurship and innovation research in Ibero-America between 1986 and 2015", Journal of Small Business Management, pp. 1-13, doi: 10.1080/00472778.2020.1776578. 
EBR

33,6

Capelleras, J.-L., Greene, F., Kantis, H. and Rabetino, R. (2010), "Venture creation speed and subsequent growth: evidence from South America", Journal of Small Business Management, Vol. 48 No. 3, pp. 302-324.

Chowdhury, F., Audretsch, D.B. and Belitski, M. (2019), "Institutions and entrepreneurship quality", Entrepreneurship Theory and Practice, Vol. 43 No. 1, pp. 51-81.

Colombo, M.G., Cumming, D.J. and Vismara, S. (2016), "Governmental venture capital for innovative young firms", The Journal of Technology Transfer, Vol. 41 No. 1, pp. 10-24.

Da Rin, M., Nicodano, G. and Sembenelli, A. (2006), "Public policy and the creation of active venture capital markets", Journal of Public Economics, Vol. 90 Nos 8/9, pp. 1699-1723.

Dams, C., Sarria Allende, V. and Murcia, M.J. (2021), "Multilateral development banks: understanding their impact on start-up development in Latin America", European Business Review, Vol. aheadof-print No. ahead-of-print, doi: 10.1108/EBR-11-2020-0274.

Espinoza-Benavides, J., Guerrero, M. and Díaz, D. (2021), "Dissecting the ecosystems' determinants of entrepreneurial re-entry after a business failure", European Business Review, Vol. ahead-of-print No. ahead-of-print, doi: 10.1108/EBR-09-2020-0222.

Fernhaber, S.A. and Mcdougall-Covin, P.P. (2009), "Venture capitalists as catalysts to new venture internationalization: the impact of their knowledge and reputation resources", Entrepreneurship: Theory and Practice, Vol. 33 No. 1, pp. 277-295.

Frare, A.B. and Beuren, I.M. (2021), "Fostering individual creativity in start-ups: comprehensive performance measurement systems, role clarity and strategic flexibility", European Business Review, Vol. ahead-of-print No. ahead-of-print, doi: 10.1108/EBR-11-2020-0262.

Fredrickson, B.L. and Losada, M.F. (2005), "Positive affect and the complex dynamics of human flourishing”, American Psychologist, Vol. 60 No. 7, p. 678.

Grilli, L. and Murtinu, S. (2014), "Government, venture capital and the growth of European high-tech entrepreneurial firms”, Research Policy, Vol. 43 No. 9, pp. 1523-1543.

Hellman, T. and Puri, M. (2000), "The interaction between product market and financing strategy: the role of venture Capital", Review of Financial Studies, Vol. 13 No. 4, pp. 959-984.

Jones, C., Matlay, H., Penaluna, K. and Penaluna, A. (2014), "Claiming the future of enterprise education”, Education + Training, Vol. 56 No. 89, pp. 764-775.

Kantis, H. (2005), "The emergence of dynamic ventures in Latin America, Southern Europe and East Asia: an international comparison", International Journal of Entrepreneurship and Small Business, Vol. 2 No. 1, pp. 34-56.

Kantis, H., Federico, J. and Girandola, M.S. (2021), "Tensiones y desafíos en la evaluación del impacto de las políticas de emprendimiento", TEC Empresarial, Vol. 15 No. 1, pp. 36-55, doi: 10.18845/te.v15i1.5392.

Kantis, H., Ishida, M. and Komori, M. (2002), Entrepreneurship in Emerging Economies: The Creation and Development of New Firms in Latin America and East Asia, Washington, DC: InterAmerican Development Bank.

Kantis, H., Gonzalo, M., Federico, J. and Garcia, S. (2020), "Entrepreneurial ecosystems meet innovation systems: Building bridges from Latin America to the global South", in Tsvetkova, A., Schmutzler, J. and Pugh, R. (Eds), Entrepreneurial Ecosystems Meet Innovation Systems, Cheltenham: Edward Elgar Publishing.

Karsai, J. (2018), "Government venture capital in central and eastern Europe”, Venture Capital, Vol. 20 No. 1, pp. 73-102.

Kelley, D., Bosma, N. and Amorós, J.E. (2011), Global Entrepreneurship Monitor 2010 Global Report, Babson College and Universidad del Desarrollo: Wellesley MA, Santiago Chile.

Khoury, T.A. and Prasad, A. (2016), "Entrepreneurship amid concurrent institutional constraints in less developed countries", Business and Society, Vol. 55 No. 7, pp. 934-969. 
Lafuente, E. and Vaillant, Y. (2021), "Pulling from the front or pushing from behind: how competency prioritisation should differ to optimise firm competitiveness", European Business Review, Vol. ahead-of-print No. ahead-of-print, doi: 10.1108/EBR-11-2020-0288.

Lafuente, E., Leiva, J.C., Moreno-Gomez, J. and Szerb, L. (2020), "A nonparametric analysis of competitiveness efficiency: the relevance of firm size and the configuration of competitive pillars", BRQ Business Research Quarterly, Vol. 23 No. 3, pp. 203-216.

Lafuente, E., Vaillant, Y., Alvarado, M., Mora-Esquivel, R. and Vendrell-Herrero, F. (2021), "Experience as a catalyst of export destinations: the ambidextrous connection between international experience and past entrepreneurial experience”, International Business Review, Vol. 30 No. 1, p. 101765.

LAVCA (2021), 2021 LAVCA Mid-Year Industry Data and Analysis, The Association for Private Capital Investment in Latin America. New York, NY, available at: https:/lavca.org/industrydata/2021-lavca-mid-year-industry-data-analysis-2/

Leporati, M., Torres Marin, A.J. and Roses, S. (2021), "Senior entrepreneurship in Chile: necessity or opportunity? A GEM perspective”, European Business Review, doi: 10.1108/EBR-11-2020-0277.

Lerner, J. (2010), Innovation, Entrepreneurship and Financial Market Cycles, OECD Publishing.

Lopez, T. and Alvarez, C. (2018), "Entrepreneurship research in Latin America: a literature review", Academia Revista Latinoamericana de Administración, Vol. 31 No. 4, pp. 736-756, doi: 10.1108/ARLA12-2016-0332.

Martínez, L. and Muñoz, J. (2021), “Are andragogy and heutagogy the secret recipe for transdisciplinary entrepreneurship education? ”, European Business Review, Vol. ahead-of-print No. ahead-ofprint, doi: 10.1108/EBR-11-2020-0290.

Martins, I., Romaní, G. and Atienza, M. (2021), "An institutional approach to the development of business angel networks in Latin American emerging countries", European Business Review, Vol. ahead-of-print No. ahead-of-print, doi: 10.1108/EBR-11-2020-0261.

Munari, F. and Toschi, L. (2015), "Assessing the impact of public venture capital programmes in the United Kingdom: do regional characteristics matter?”, Journal of Business Venturing, Vol. 30 No. 2, pp. 205-226.

OECD (2021), OECD Employment Outlook 2021: Navigating the COVID-19 Crisis and Recovery, OECD Publishing, Paris, doi: 10.1787/5a700c4b-en.

Peres, W. and Stumpo, G. (2002), Small and Medium-Sized Industrial Enterprises in Latin America and the Caribbean, ECLAC: Twenty-first Century Editors

Sala-I-Martin, X., Blanke, J., Drzeniek Hanouz, M., Geiger, T. and Mia, I. (2010), "The global competitiveness index 2010-2011: looking beyond the global economic crisis", in Schwab, K. (Ed.), The Global Competitiveness Report 2010-2011, Geneva: World Economic Forum, pp. 3-55.

Silveyra, G., Rodríguez-Aceves, L., Charles-Leija, H. and Saiz-Álvarez, J.M. (2021), "Human flourishing: an enabler of entrepreneurial intention in Latin American students", European Business Review, Vol. ahead-of-print No. ahead-of-print, doi: 10.1108/EBR-11-2020-0283.

Stel, AV., Carree, M. and Thurik, R. (2005), "The effect of entrepreneurial activity on national economic growth", Small Business Economics, Vol. 24 No. 3, pp. 311-321.

Terjesen, S. and Amorós, J.E. (2010), "Female entrepreneurship in Latin America: individual and economic institution characteristics of opportunity and necessity-based activity", The European Journal of Development Research, Vol. 22 No. 3, pp. 313-330.

Tiffin, S. (2004), Entrepreneurship in Latin America, Westport, CT: Praeger.

Wennekers, S., Stel, AV., Thurik, R. and Reynolds, P. (2005), "Nascent entrepreneurship and the level of economic development”, Small Business Economics, Vol. 24 No. 3, pp. 293-309.

West, G.P., Bamford, C.E. and Marsden, J.W. (2008), "Contrasting entrepreneurial economic development in emerging Latin American economies: applications and extensions of resourcebased theory", Entrepreneurship Theory and Practice, Vol. 32 No. 1, pp. 15-36. 
EBR

33,6

848
World Bank (2020), "Poverty and share prosperity 2020: reversals of fortune”, Washington DC, The International Bank for Reconstruction and Development/The World Bank.

\section{Further reading}

Amorós, J.E., Fernández, C. and Tapia, J. (2012), "Quantifying the relationship between entrepreneurship and competitiveness development stages in Latin America", International Entrepreneurship and Management Journal, Vol. 8 No. 3, pp. 249-270.

Puente, R., González Espitia, C.G. and Cervilla, M.A. (2019), "Necessity entrepreneurship in Latin America: it"s not that simple", Entrepreneurship and Regional Development, Vol. 31 Nos 9/10, pp. 953-983.

For instructions on how to order reprints of this article, please visit our website: 